\title{
A 5-deoxyflavonol derivative in Mimosa pudica
}

Kirk, Lars F.; Møller, Mette V.; Christensen, Jette; Stærk, Dan; Ekpe, Patrick; Jaroszewski, Jerzy W.

Published in:

Biochemical Systematics and Ecology

Publication date:

2003

Document version

Publisher's PDF, also known as Version of record

Citation for published version (APA):

Kirk, L. F., Møller, M. V., Christensen, J., Stærk, D., Ekpe, P., \& Jaroszewski, J. W. (2003). A 5-deoxyflavonol derivative in Mimosa pudica. Biochemical Systematics and Ecology, 31(1), 103-105. 


\title{
A 5-deoxyflavonol derivative in Mimosa pudica
}

\author{
Lars F. Kirk a, Mette V. Møller a, Jette Christensen a, \\ Dan Stærk ${ }^{\mathrm{a}, *}$, Patrick Ekpe ${ }^{\mathrm{b}}$, Jerzy W. Jaroszewski ${ }^{\mathrm{a}}$ \\ ${ }^{a}$ Department of Medicinal Chemistry, Royal Danish School of Pharmacy, Universitetsparken 2, DK- \\ 2100 Copenhagen, Denmark \\ ${ }^{\mathrm{b}}$ Department of Botany, University of Ghana, P.O. Box LG55, Legon, Ghana
}

Received 1 November 2001; accepted 30 January 2002

Keywords: Mimosa pudica; 7,3',4'-Trihydroxy-3,8-dimethoxyflavone; 7,3',4'-Triacetoxy-3,8-dimethoxyflavone; $p$-Coumaric acid; Nyctinastic movement; Leguminosae; Mimosoideae; Chemotaxonomy

\section{Subject and source}

Aerial parts of Mimosa pudica L. (Leguminosae-Mimosoideae) were collected near Accra, Ghana. Voucher specimen (GC47684) was deposited in Herbarium GC (Ghana Herbarium, Botany Department, University of Ghana, Legon).

\section{Previous work}

The interest in M. pudica (the so-called sensitive plant) has mainly been concerned with chemistry and biology of the thigmonastic movement (rapid leaf movement observed upon touching the leaves) and nyctinastic movement (slow movement controlled by a biological clock) of the leaves, and several leaf-movement factors have been refined (Kameyama et al., 2000; Ueda and Yamamura, 2000; Ueda et al., 2000). Phenolics (Ueda et al., 2000; Josewin et al., 1999; Englert et al., 1994), norepinephrine (Applewhite, 1973) and a non-protein amino acid leucenine (mimosine) (Kleipool and Wibaut, 1950) have been isolated. A saponin (Jiang et al., 1990) and a bufadienolide (Yadava and Yadav, 2001) were reported in M. pudica seeds.

\footnotetext{
* Corresponding author. Tel.: +45-3530-6413; fax: +45-3530-6040.
}

E-mail address: ds@dfh.dk (D. Stærk). 
<smiles>COc1ccc(-c2oc3c(OC)c(O)ccc3c(=O)c2OC)cc1O</smiles><smiles>O=C(O)C=Cc1ccc(O)cc1</smiles>

$$
\begin{aligned}
& 1 \mathrm{R}=\mathrm{H} \\
& \mathbf{2} \mathrm{R}=\mathrm{COCH}_{3}
\end{aligned}
$$

\section{Present study}

Dried leaves of $M$. pudica $(1.35 \mathrm{~kg})$ were extracted with $96 \%$ ethanol $(5 \times 2 \mathrm{l})$, the extract evaporated, and the residue distributed between $\mathrm{MeOH}-\mathrm{H}_{2} \mathrm{O}(9: 1), \mathrm{EtOAc}$ and light petroleum (bp $\left.80-110{ }^{\circ} \mathrm{C}\right)$. The EtOAc fraction $(10.7 \mathrm{~g})$ was further fractionated by VLC (Merck silica gel $60 \mathrm{H}$, step gradient of $\mathrm{MeOH}$ in $\mathrm{CH}_{2} \mathrm{Cl}_{2}$ ) and the product finally isolated by HPLC $\left(250 \times 4.6 \mathrm{~mm}\right.$ Waters Symmetry $\mathrm{C}_{18}$ column, 5 $\mu \mathrm{m}$, linear $\mathrm{MeCN}$ gradient in $\mathrm{H}_{2} \mathrm{O}$ from $5 \%$ to $95 \%$ over $25 \mathrm{~min}$ ), to give $16 \mathrm{mg}$ of 7,3',4'-trihydroxy-3,8-dimethoxyflavone (1). The structure could be established unambiguously using NOESY (mixing time 500-700 ms) and HMBC (delay for evolution of long-range couplings $30-100 \mathrm{~ms}$ ) connectivities. ${ }^{1} \mathrm{H}$ NMR data (400 $\left.\mathrm{MHz}, \mathrm{CD}_{3} \mathrm{OD}\right) \delta 7.75\left(1 \mathrm{H}, \mathrm{d}, J_{5,6}=8.9 \mathrm{~Hz}, \mathrm{H}-5\right), 6.98\left(1 \mathrm{H}, \mathrm{d}, J_{5,6}=8.9 \mathrm{~Hz}, \mathrm{H}-\right.$ 6), $7.72\left(1 \mathrm{H}, \mathrm{d}, J_{2^{\prime}, 6^{\prime}}=2.2 \mathrm{~Hz}, \mathrm{H}-2^{\prime}\right), 6.93\left(1 \mathrm{H}, \mathrm{d}, J_{5^{\prime}, 6^{\prime}}=8.5 \mathrm{~Hz}, \mathrm{H}-5^{\prime}\right), 7.63(1 \mathrm{H}$, $\left.\mathrm{dd}, J_{5^{\prime}, 6^{\prime}}=8.5 \mathrm{~Hz}, J_{2^{\prime}, 6^{\prime}}=2.2 \mathrm{~Hz}, \mathrm{H}-6^{\prime}\right), 3.79(3 \mathrm{H}, \mathrm{s}, 3-\mathrm{OMe}), 4.01$ (3H, s, 8-OMe). ${ }^{13} \mathrm{C}$ NMR data $\left(100 \mathrm{MHz}, \mathrm{CD}_{3} \mathrm{OD}\right) \delta 157.7$ (C-2), 141.2 (C-3), $176.7(\mathrm{C}-4), 121.7$ (C-5), 116.4 (C-6), 156.8 (C-7), 136.5 (C-8), 151.5 (C-9), 118.7 (C-10), 123.4 (C$\left.1^{\prime}\right), 116.5\left(\mathrm{C}-2^{\prime}\right), 146.6\left(\mathrm{C}-3^{\prime}\right), 149.9\left(\mathrm{C}-4^{\prime}\right), 116.5(\mathrm{C}-5), 122.4\left(\mathrm{C}-6^{\prime}\right), 60.4$ (3$\mathrm{OMe}), 62.1$ (8-OMe). The compound ( $2 \mathrm{mg}$ ) was acetylated with $\mathrm{Ac}_{2} \mathrm{O} /$ pyridine to give (2). ${ }^{1} \mathrm{H}$ NMR data $\left(400 \mathrm{MHz}, \mathrm{CD}_{3} \mathrm{OD}\right) \delta 8.05\left(1 \mathrm{H}, \mathrm{d}, J_{5,6}=8.7 \mathrm{~Hz}, \mathrm{H}-5\right), 7.11$ $\left(1 \mathrm{H}, \mathrm{d}, J_{5,6}=8.7 \mathrm{~Hz}, \mathrm{H}-6\right), 8.09\left(1 \mathrm{H}, \mathrm{d}, J_{2^{\prime}, 6^{\prime}}=2.2 \mathrm{~Hz}, \mathrm{H}-2^{\prime}\right), 7.37(1 \mathrm{H}, \mathrm{d}$, $\left.J_{5^{\prime}, 6^{\prime}}=8.6 \mathrm{~Hz}, \mathrm{H}-5^{\prime}\right), 8.08\left(1 \mathrm{H}, \mathrm{dd}, J_{5^{\prime}, 6^{\prime}}=8.6 \mathrm{~Hz}, J_{2^{\prime}, 6^{\prime}}=2.2 \mathrm{~Hz}, \mathrm{H}-6^{\prime}\right), 3.93(3 \mathrm{H}$, s, 3-OMe), 4.02 (3H, s, 8-OMe), 2.34, 2.35, 2.40 (each $3 \mathrm{H}, \mathrm{s}, \mathrm{OAc}$ ). The ${ }^{1} \mathrm{H}$ and ${ }^{13} \mathrm{C}$ data of $(\mathbf{1})$, not reported previously, are of value for reference purposes; the ${ }^{1} \mathrm{H}$ NMR data of (2) confirm the identity of (1) with the compound isolated from Acacia kempeana heartwood (Clark-Lewis and Porter, 1972). During HPLC purification of (1), $4 \mathrm{mg}$ of $p$-coumaric acid (3) was isolated, the structural assignment being based on ${ }^{1} \mathrm{H}$ and ${ }^{13} \mathrm{C}$ NMR data (Gerothanassis et al., 1998; Nikaido et al., 1987). 


\section{Chemotaxonomic significance}

Compound (1) belongs to an unusual group of flavonoids in which the oxygen at C-5 is lost during the biosynthesis (Sallaud et al., 1995). Such compounds are characteristic of the Leguminosae (Hegnauer and Grayer-Barkmeijer, 1993), where the 5hydroxy- and the 5-deoxyflavonoids co-occur as the result of co-acting of chalcone reductase and chalcone synthase (Sallaud et al., 1995). Compound (1) was encountered only once before, in Acacia kempeana (Clark-Lewis and Porter, 1972), and represents the first report of a 5-deoxyflavonoid in Mimosa.

5-Deoxyflavonols with the same oxygenation level as in (1) have previously been isolated from many Acacia (Malan and Swartz, 1995; Malan, 1993; Foo, 1987; ClarkLewis and Porter, 1972; Clark-Lewis and Nair, 1964; King and Bottomley, 1954) and several Albizzia species (Candy et al., 1978; Deshpande and Shastri, 1977). To the best of our knowledge, they have not been reported from other genera of Leguminosae. Thus, 5-deoxyflavonols with oxygens at C-7, C-8, C-3' and C-4' found in Acacia, Albizzia and Mimosa appear to be restricted to Mimosoideae.

$p$-Coumaric acid (3) is a common plant constituent. Coumaric acid derivatives act as leaf-opening substances in other nyctinastic plants (Ueda et al., 2000).

\section{References}

Applewhite, P.B., 1973. Phytochemistry 12, 191.

Candy, H.A., Brookes, K.B., Bull, J.R., McGarry, E.J., McGarry, J.M., 1978. Phytochemistry $17,1681$. Clark-Lewis, J.W., Porter, L.J., 1972. Aus. J. Chem 25, 1943.

Clark-Lewis, J.W., Nair, V., 1964. Aus. J. Chem 17, 1164.

Deshpande, V.H., Shastri, R.K., 1977. Ind. J. Chem. Sect. B 15, 201.

Englert, J., Jiang, Y., Cabalion, P., Oulad-Ali, A., Anton, R., 1994. Planta Med 60, 194.

Foo, L.Y., 1987. Phytochemistry 26, 813.

Gerothanassis, I.P., Exarchou, V., Lagouri, V., Troganis, A., Tsimidou, M., Boskou, D., 1998. J. Agric. Food Chem 46, 4185.

Hegnauer, R., Grayer-Barkmeijer, R.J., 1993. Phytochemistry 34, 3.

Jiang, Y., Haag, M., Quirion, J.C., Cabalion, P., Kuballa, B., Anton, R., 1990. Planta Med 56, 555.

Josewin, B., Ramachandrapai, M., Suseelan, M.S., 1999. Ind. J. Chem. Sect. B 38, 251.

Kameyama, K., Kishi, Y., Yoshimura, M., Kanzawa, N., Sameshima, M., Tsuchiya, T., 2000. Nature 407, 37.

King, F.E., Bottomley, W., 1954. J. Chem. Soc. 1399.

Kleipool, R.J.C., Wibaut, J.P., 1950. Rec. Trav. Chim 69, 37.

Malan, E., 1993. Phytochemistry 33, 733.

Malan, E., Swartz, P., 1995. Phytochemistry 39, 791.

Nikaido, T., Ohmoto, T., Sankawa, U., 1987. Chem. Pharm. Bull 35, 675.

Sallaud, C., El-Turk, J., Breda, C., Buffard, D., de Kozak, I., Esnault, R., Kondrosi, A., 1995. Plant Sci $109,179$.

Ueda, M., Shigemori, H., Sata, N., Yamamura, S., 2000. Phytochemistry 53, 39.

Ueda, M., Yamamura, S., 2000. Angew. Chem. Int. Ed. Engl 39, 1400.

Yadava, R.N., Yadav, S., 2001. Asian J. Chem 13, 1157. 